\title{
THE PROBLEM OF THE NON-JUSTICIABILITY OF RELIGIOUS DEFAMATIONS
}

\author{
Peter Smith*
}

\section{INTRODUCTION}

English law has long held the principle that religions should be free from interference by the state in certain matters. The original 1215 edition of the Magna Carta proclaimed, as its first article, "THAT WE HAVE GRANTED TO GOD, and by this present charter have confirmed for us and our heirs in perpetuity, that the English Church shall be free, and shall have its rights undiminished, and its liberties unimpaired."

This article was intended to protect the established Catholic Church from the powers of the state, specifically from interference in church elections by the executive in the form of the person of the monarch. The notion that religions were institutions with practices and beliefs that were outside the control of the state in certain respects was adopted by the common law and is found in modern times in the principle of nonjusticiability on the matter of religion in certain types of civil case. ${ }^{2}$

In recent years, the position has been summarised as "the courts will not attempt to rule upon doctrinal issues or intervene in the regulation or governance of religious groups."3

\footnotetext{
* Employed barrister, Carter-Ruck, 6 St Andrew Street, London, EC4A 3AE.

1 'English Translation of Magna Carta' (British Library)<www.bl.uk/magnacarta/articles/magna-carta-english-translation> accessed 7 July 2015. Specifically, the article protected the 'freedom of the Church's elections': 'This freedom we shall observe ourselves, and desire to be observed in good faith by our heirs in perpetuity.' This was reiterated in the final peroration at article 63: 'IT IS ACCORDINGLY OUR WISH AND COMMAND that the English Church shall be free...'

2 Also known as the "“non-interference" principle': see Russell Sandberg, Law and Religion (CUP 2011) 74-76. It does not apply to the Church of England as the Established church: see Mark Hill, Russell Sandberg and Norman Doe, Religion and Law in the United Kingdom (2nd edn, Wolters Kluwer 2014) 76.

${ }^{3}$ Blake v Associated Newspapers Limited [2003] EWHC 1960 (QB) [5] (Eady J).
} 


\section{THE PROBLEM OF THE NON-JUSTICIABILITY OF RELIGIOUS DEFAMATIONS}

Religion...is not the business of government or of the secular courts...The starting point of the law is an essentially agnostic view of religious beliefs and a tolerant indulgence to religious and cultural diversity... It is not for a judge to weigh one religion against another. All are entitled to equal respect. ${ }^{4}$

This non-interference has been described as both active, "through the express grant and preservation of rights of self-determination, selfgovernance and self-regulation", and passive, "through non-interference on the part of organs of State such as national government local or regional government or the secular courts. In the United Kingdom there is no systematic provision made for autonomy of religious organizations and, in the main, a self-denying ordinance of neutrality may be said to predominate."

One area of law where the passive conception has been particularly adopted is in the law of defamation. This is, perhaps, surprising: many religions specifically proscribe libel and particularly slander as forms of wrongdoing. In the Bible, the Psalmist prays, "Set a watch, O Lord, before my mouth; and a door round about my lips". 6 The Book of Proverbs warns, "He that utterth a slander, is a fool" and "Do not slander a slave to his master, or he will curse you and you will be found guilty." $\mathrm{St}$ Matthew records Jesus telling his listeners, "But I tell you that every careless word that people speak, they shall give an accounting for it in the Day of Judgment.",

Despite these injunctions, English law, which has otherwise been so deeply rooted in Christian principle, does not reflect this prohibition when it comes to the matter of religion and libel, as it did until recently with blasphemy and as it does with defamation generally. ${ }^{10}$ This is partly

\footnotetext{
${ }^{4}$ Sulaiman v Juffali [2001] EWHC 556 (Fam) [47] (Munby J).

${ }^{5}$ Doe, Religion and Law in the United Kingdom (n 2).

${ }^{6}$ Psalms 143:3.

${ }^{7}$ Proverbs 10:18.

${ }^{8}$ Proverbs 30:10.

${ }^{9}$ Matthew 12:36.

${ }^{10}$ Blasphemy was long a common law and statutory offence which defied neat definition, see the Law Commission, Offences Against Religion and Public Worship (working paper 79 1981) 5-6: 'there is no one agreed definition of blasphemy and blasphemous libel' - but it is often characterised as the defamation of religion. Prosecutions for blasphemy became increasingly rare; the last by the Crown was in 1922 and the only other prosecution before the crime was abolished by Criminal Justice \& Immigration Act 2008, s 79 was a private
} 
the cultural product of the Reformation. The sectarian violence of the period gradually gave way to the acceptance of religious difference in the liberal state, which had neither the knowledge nor the desire to investigate the truth of what were ultimately profound differences in belief between Catholic, Anglican and Non-Conformist theology. ${ }^{11}$ How could a court decide when a Catholic labelled a Protestant a heretic, for instance, or when one Methodist described another as schismatic?

When the courts did intervene, it was only because of the implied or explicit accusation of another wrong that accompanied a religious libel. It was, for instance, once an actionable libel to call a person a "Papist" and allege that they went to Mass, because of the imputation of criminality and disloyalty that was implied by the accusation. ${ }^{12}$ Gradually, public opinion has changed and it is clearly no longer the case today that, in England, being Catholic carries the same implied sting in the minds of the public. $^{13}$

Defamation law applied to religion is unstable and, as both a cause and a symptom of the cultural shift towards freer speech, defamation law itself has also changed markedly in very recent years. The pendulum has swung away from the right to reputation and towards free expression with the coming into force of the Defamation Act 2013. This introduced the hurdle of proving a statement has caused or is likely to cause "serious harm" to the reputation of the claimant. ${ }^{14}$ It has also reformulated some of the substantial defences to a claim for libel in the new statutory defences

prosecution in 1978. See the history of the crime in the House of Lords' judgments in Whitehouse v Lemon; Whitehouse v Gay News Ltd [1979] 2 WLR 281 (HL).

${ }^{11}$ Sandberg, Law and Religion (n 11) ch 2. Sandberg describes four phases in the historical development of religion and law: the 'temporal-spiritual partnership' which followed the Norman Conquest; 'the era of discrimination and tolerance' which resulted from the Reformation; the 'epoch of toleration' which followed the Glorious Revolution; and 'the current age of positive religious freedom' stemming from the 1998 Human Rights Act.

${ }^{12}$ Row v Sir Thomas Clargis (1681) 83 ER 252.

13 Other common law jurisdictions, however, have a different culture against which to judge the imputation of a libel. In Chen Cheng $v$ Central Christian Church [1999] 1 Sing LR 94 Sing (CA), it was held that calling a church a 'cult' was defamatory because in Singapore the word was a pejorative one, meaning a religious group with teachings and practices that are abhorrent and harmful to society. See Richard Parkes and others, Gatley on Libel and Slander (12th edn, Sweet \& Maxwell 2013) ch 2, fn 213.

${ }^{14}$ On the background to the 2013 Act, see ch 1 of James Price QC and Felicity McMahon, Blackstone's Guide to the Defamation Act 2013 (OUP 2013). 


\section{THE PROBLEM OF THE NON-JUSTICIABILITY OF RELIGIOUS DEFAMATIONS}

of truth, honest opinion and publication on matter of public interest, introduced new defences, and extended existing ones. ${ }^{15}$

The UK Supreme Court decision in Shergill $v$ Khaira presents a challenge to the principle of non-justiciability in the case of religious defamation. ${ }^{16}$ The application of the principle in the case of Blake $v$ Associated Newspapers Ltd was "not...correct". ${ }^{17}$ Courts should not decline jurisdiction on the grounds of religion, even if they raise questions of doctrine and ecclesiology, if the claim is grounded in a valid cause of action such as libel: "the court will enter into questions of disputed doctrine if it is necessary to do so in reference to civil interests". ${ }^{18}$

This decision ostensibly gives the court jurisdiction to decide deep questions of religion and opens to claimants the right to vindicate their reputation when previously such an action would have been denied to them. However, this boon for claimants may be countered by an extension of the defence of honest opinion for defendants, as the Supreme Court itself notes. ${ }^{19}$

\section{DEFAMATION ACTIONS IN RELIGIOUS CONTEXTS GENERALLY}

It has been suggested that there are four types of dispute that include a "religious dimension". 20

15 Formerly, the defences of justification, fair comment, and responsible journalism. New defences include protection for the operators of websites and for peer-reviewed statements in scientific or academic journals. Extended defences include reports protected by privilege. See Blackstone's Guide to the Defamation Act 2013, chs 3-9.

${ }^{16}$ [2014] UKSC 33, hereafter 'Khaira'.

17 [2003] EWHC 1960 (QB).

${ }^{18}$ Ibid [57].

19 'The problem that such defamation claims face, which will usually doom them to failure, is that they raise issues of religious opinion on which people may hold opposing views in good faith. The expression of such views without malice is likely to be protected by the defence of honest comment - what used, until Joseph $v$ Spiller [2011] 1 AC 852, to be called fair comment.' ibid.

${ }^{20}$ Alastair Mullis and Andrew Scott, 'How to Know the Truth: Accommodating Religious Belief in the Law of Libel' (hereafter, 'Mullis and Scott') ch 8 in James Richardson and Francois Bellanger (eds), Legal Cases, New Religious Movements, and Minority Faiths (Ashgate 2010). Also available at LSE Law, Society and Economy Working Papers 9/2012:

<www.lse.ac.uk/collections/law/wps/WPS2012-09_Scott.pdf> accessed 8 July 2015. 
First, general criticism of religions which, if deemed offensive to followers of the religion, may be caught by group defamation or blasphemy laws. General criticism of a religion does not found an action for libel unless a particular follower can establish that the criticism applies to him, however. ${ }^{21}$ This is why it is not actionable as a tort for a priest to sue on the allegation that all Catholics are child-abusers, nor for an imam to bring a claim against the publisher because of the assertion that all Muslims are terrorists, although criminal law may apply. ${ }^{22}$

Second specific allegations may be caught when made against particular individuals alleging that they have failed to meet prescribed standards or expectations of behaviour, e.g. that they have sinned against the religion. But individuals impugned in this way are perhaps more likely to use internal dispute resolutions than secular courts, in a bid to stay within the organisation. ${ }^{23}$

There are two further sorts of religious dispute which have historically led to libel actions that invoke the secular law. These are when general criticisms are made of a religion coupled with specific, associated criticism of a particular person such that they can sue, or when criticism of the religion is made without a basis in religious doctrine. These forms are

21 In English law, there must be specificity before a person, whether legal or natural, can bring a defamation action. On the need for sufficient reference to the claimant, see Orme $v$ Associated Newspapers, The Times 4 February 1981 (Comyn J). The judge held that an article about the Moonies was capable of referring to the leader in England of that new minority religion. In that case, the grave charges must have been capable of referring to the plaintiff if only because people might say that he must have known what went on. See Hardeep Singh, 'Religious Libel: Are the Courts the Right Place for Faith Disputes?' (hereafter, 'Religious Libel') 152-54, ch 9 in Legal Cases, New Religious Movements, and Minority Faiths, ibid; and Mullis and Scott (n 20) fn 9, 134.

22 An exceptional case is Ortenburg v Plamondon (1914) 24 Quebec KB 69, decided under the Civil Law of Quebec but referring to common law cases, the defendant, in a lecture delivered in the City of Quebec, violently assailed and abused the Jewish race, its religious doctrines and social practices, the object being to put the public of Quebec on guard against the Jews of Quebec, who numbered only 75 families in a total population of 80,000 souls. It was held that although not assailed individually, the plaintiff, being one of the "restricted collectivity" of the Jews of Quebec, was entitled to maintain an action of defamation against the defendant. See Gatley on Libel and Slander (n 13) 7.97.10 .

${ }^{23}$ See Frank Otuo $v$ The Watchtower Bible and Tract Society of Britain [2013] (unrep but available at <https://inforrm.wordpress.com/table-of-cases-2/> accessed 1 July 2015) (HHJ Moloney QC) for an example of where the expulsion of a Jehovah's Witness member triggered a libel claim. 


\section{THE PROBLEM OF THE NON-JUSTICIABILITY OF RELIGIOUS DEFAMATIONS}

distinguished from each other by asking "whether or not the imputations at issue rest upon a doctrinal dispute". ${ }^{24}$

There are many examples of allegations being made without a basis in religious doctrine, as noted above. ${ }^{25}$ It has been held defamatory to state of an archbishop of the Church of Ireland that he has attempted to convert a Catholic priest to Protestantism by an offer of $£ 1,000$ in cash and a living of $£ 800$ a year, ${ }^{26}$ or to state of a clergyman that he is guilty of immorality or drunkenness, ${ }^{27}$ or that he preaches sedition, ${ }^{28}$ lies, ${ }^{29}$ or that he knows less about his religion than an adolescent, ${ }^{30}$ or that he has used his pulpit to throw out personal invectives against a member of the congregation, ${ }^{31}$ or that he has juggled with the collections, ${ }^{32}$ or that he has desecrated a part of his church by turning it into a cooking department. ${ }^{33}$ Indeed, the religious context of an accusation can be taken into account, even if the action is without a basis in religious in doctrine. ${ }^{34}$

If the allegation is that a clergyman preached false doctrine, it will be defamatory if, in the circumstances, it imputed hypocrisy. But if the defendant belonged to a different church to the claimant and the churches

${ }^{24}$ Mullis and Scott (n 20) 141.

25 See Gatley on Libel and Slander (n 13) 2.40, from where the following examples are drawn. More recent examples include Sharma v Sharma [2014] EWHC 3349 involving allegations of criminality after the defendant was replaced by the claimant on the board of a national Hindu charity.

${ }^{26}$ Archbishop of Tuam v Robeson (1828) 5 Bing 17.

27 Payne $v$ Beaumorris (1661) 1 Lev 248; Evans $v$ Gwyn (1844) 5 QB 844; Gallwey v Marshall (1853) 9 Exch 294; Stow v Gardner (1843) 6 Up Can QB (OS) 512; Steltzer v Domm [1932] 2 WWR 139. Words which, if directed against another would not be defamatory may be so if directed against a clergyman, because of the nature of the calling: Murphy v Harty, 393 P 2d 206 (Or 1964).

${ }^{28}$ Cranden $v$ Walden (1693) 3 Lev 17.

${ }^{29}$ Phillips v Badley (1582) cited 4 Co Rep at 19a; Drake v Drake (1652) Style 363.

${ }^{30}$ Maidman v Jewish Publications (1960) 54 Cal 2d 643.

${ }^{31}$ Edwards v Bell (1824) 1 Bing 403.

${ }^{32}$ Curtis v Argus (1915) 155 NY S 813; Dr Sibthorp's Case (1628) W Jones 366.

${ }^{33}$ Kelly v Sherlock (1866) LR 1 QB 686.

${ }^{34}$ Maccaba v Lichtenstein [2004] EWHC 1580 (QB) [9] (Gray J). However, in another religious slander case albeit one under a different statutory regime, the claimant's declaration that she had been expelled from her religious congregation and had been unable to join another, was not actionable absent proof of special damage: Roberts v Roberts 16 (1864) 5 B\&S 384. 
are in disagreement about the doctrine, it will not be an actionable tort. ${ }^{35}$ This key distinction is at the heart of the non-justiciability problem.

\section{THE KHAIRA LITIGATION IN THE LOWER COURTS}

Khaira was one of a number of suits (along with Baba Jeet $v$ Singh $^{36}$ and Shergill $v$ Purewal) ${ }^{37}$ that stemmed from the overspill of a dispute in India to the Sikh community in the $\mathrm{UK}^{38}$ The underlying dispute concerned the declaration of a mahant, or religious superior of a dera (monastery) in the Punjab, known in proceedings as the First Holy Saint, that he was a living guru and so a religious leader of great importance to Sikhs. The order he founded, the Nirmal Kutia Johal, set up three gurdwaras in the UK, in Bradford, Birmingham and High Wycombe. He died in 2001 and was succeeded in short order by the Second and then Third Holy Saint. ${ }^{39}$

In Khaira, eight of the appellants contended that they had been validly appointed as trustees of the three gurdwaras by the Third Holy Saint. They sought declarations that this was done under the relevant trust deeds, which allowed the First Holy Saint "and his successor" to remove and appoint trustees. The respondents, the original trustees of the gurdwaras, argued that the Third Holy Saint had no power to remove and appointed trustees of the gurdwaras.

The judge at first instance dismissed the defendants' application for strike out on the grounds of non-justiciability, considering that the legal question of the construction of the deeds required "not an establishment of the propriety or the validity of a process by which the [Third Holy Saint] may have succeeded to come to be regarded as holding the office of Holy Saint but whether, as a matter of fact, he has become sufficiently recognised as the holder of that office to be considered to be a person

${ }^{35}$ See Dod v Robinson (1648) Aleyn 63; Gatley on Libel and Slander (n 13) fn 417.

${ }^{36}$ [2010] EWHC 1294 (QB). AKA His Holiness Sant Bab Jeet Singh Ji Maharaj v (1) Eastern Media Group Limited (2) Hardeep Singh

${ }^{37}$ [2010] EWHC 3610 (QB).

${ }^{38}$ For a brief exposition of the Sikh community in the UK, see Singh 'Religious Libel' (n 21) 157. Singh himself was a defendant (along with his publisher, the Sikh Times) in the libel case of Baba Jeet $v$ Singh, when he was sued by the Third Holy Saint. He explains the background to the religious dispute at 158-165.

${ }^{39}$ The background facts are set out in the Court of Appeal judgment Shergill $v$ Khaira [2012] EWCA Civ 983 [28] - [36] (Mummery LJ), and in Khaira (n 16) [2] - [11]. 


\section{THE PROBLEM OF THE NON-JUSTICIABILITY OF RELIGIOUS DEFAMATIONS}

described as having a particular power in the English deed, the construction of which is before the court [emphasis added]. ${ }^{, 40}$ If the Third Holy Saint was accepted as de facto "successor" by a sufficient number of adherents of the Nirmal Kutia Johal, even if a minority disagreed, then that would be enough to make appropriate findings of fact and construe the documents accordingly.

The Court of Appeal was invited to reject this approach on a number of bases, including whether the standpoint adopted by the judge, which purported to be objective, from the perspective of English law and without a view on Sikh doctrine or practice, was skewed in accepting that the Third Holy Saint could be de facto "successor" without being de jure "successor" to the First Holy Saint in the eyes of the Sikh religion. ${ }^{41}$

In Mummery LJ's view (giving the sole judgment, joined by Hooper and Pitchford LJJ), the decision in Buttes Gas and Oil v Hammer (No 3$)^{42}$ as sufficient authority for the proposition that, if a purportedly secular dispute on the construction of a deed in English law turned fundamentally on a dispute on religious doctrine, the absence of "judicial or manageable standards by which to judge these issues" put the matter outside the jurisdiction of the courts. ${ }^{43}$ Contrary to the claimants' plea that there was a "bond of union" (a contract or agreement) between the parties that provided sufficient objective standards, this was a case where "judicial self-restraint" was required, as the subject-matter of the religious dispute defied "analysing evidence, or by finding facts on the balance of probability, or by counting heads, or by ascertaining the wishes of a voting majority." 44 The deeds themselves did not provide any way to consider the meaning of "successor" without delving into the religious dispute, "essentially a matter of professed subjective belief and faith on which secular municipal courts cannot possibly reach a decision, either as a matter of law or fact.... This court should put a halt to this case now. $" 45$

\footnotetext{
${ }^{40}$ Khaira $v$ Shergill [2013] EWHC 4162 (Ch) [22] - [25] (HHJ Cooke).

${ }^{41}$ See Mummery LJ in CA [51] - [56]. As the headnote put it, 'it was not simply a question of the meaning of word "successor", but whether [the Third Holy Saint] fitted that description'.

42 [1982] AC 888, in which the House of Lords considered a claim for slander whose true goal was to obtain a decision of the English court about the boundary between the territory of three Gulf states, which affected the parties' off-shore drilling rights.

${ }^{43}$ Shergill (n 39) [15], quoting Lord Wilberforce in Buttes 938B-C.

${ }^{44}$ Ibid [16], [59], [70]-[71].

${ }^{45}$ Ibid [72]-[73].
} 


\section{KHAIRA IN THE SUPREME COURT}

The single judgment in the Supreme Court differed with Mummery LJ's understanding of Buttes Gas. That case was non-justiciable because it was inherently political and involved the transactions of foreign sovereign states: "it trespassed on the proper province of the executive, as the organ of the state charged with the conduct of foreign relations", as well as the lack of "judicial or manageable standards" as Mummery LJ identified, making it "difficult to imagine that such a conclusion could have been reached in any other context than the policy acts of sovereign states, for the acts of private parties, however political, are subject to law." 46 The implication here is that, although religious matters may fall under the second quality of political matters, they do not fall under the first, and thus there is no inherent non-justiciability in matters of religion.

A case is non-justiciable "where an issue is said to be inherently unsuitable for judicial determination by reason only of its subject matter", for two reasons. ${ }^{47}$ Firstly, there was a "rare" class of disputes where the issue was beyond the "constitutional competence assigned to the courts under our conception of the separation of powers", and once the "forbidden" area was identified, including certain transactions of foreign states and of proceedings in Parliament, the court could not adjudicate on matters within it, even if necessary to decide some other justiciable issue (if it "inhibits the defence of a claim, this may make it necessary to strike out an otherwise justiciable claim on the ground that it cannot be fairly tried"). ${ }^{48}$

The court also proposed a second, "quite different" basis for nonjusticiability: "claims or defences which are based neither on private legal rights or obligations, nor on reviewable matters of public law", such as "domestic disputes, transactions not intended by the participants to affect their legal relations, and [certain] issues of international law." Disputes in this category may, however, be entertained by "reluctant" courts if a legal right is engaged. ${ }^{49}$

\footnotetext{
${ }^{46}$ Ibid [40].

${ }^{47}$ Non-justiciability was juxtaposed to other matters, such as state immunity, the act of state doctrine, and unenforceability of foreign penal, revenue or public laws, which are 'generally questions of territorial limits of the competence' of English courts or the competence the courts recognise in foreign courts: ibid [41]. 48 Ibid [42]. See Prebble v Television New Zealand [1995] 1 AC 321 and Hamilton v Al-Fayed [2001] 1 AC 395.

49 Ibid [43]; see the Lord Bingham quote from $R$ (Gentle) $v$ Prime Minister [2008] 1 AC 1356.
} 


\section{THE PROBLEM OF THE NON-JUSTICIABILITY OF RELIGIOUS DEFAMATIONS}

The Court cited a Canadian Supreme Court case, where a promise to obtain a Jewish religious divorce made by a husband to his wife was enforceable as a civil contract and was not merely a religious and moral obligation, in support of the proposition that the court is "not barred from considering a question of a religious nature, provided that the claim is based on the violation of a rule recognized in positive law". 50

The Court set out the limited instances where this might happen. A line of English and Scots law cases show how "where a claimant asks the court to enforce private rights and obligations which depend on religious issues, the judge may have to determine such religious issues as are capable of objective ascertainment." belief and practice where the court"s jurisdiction is invoked either (a) to enforce the contractual rights of members of a community against other members or its governing body, or (b) to ensure that property held on trust is used for the purposes of the trust. ${ }^{52}$

The Supreme Court also rejected two bases of non-justiciability of religious disputes. The first related to public law. The well-known decision in ex parte Wachmann, that the Chief Rabbi's decision that the applicant was not religiously and morally fit to hold office as a rabbi did not raise an issue of public law which was amenable to judicial review, was "not an authority for a proposition that the legality of such disciplinary proceedings is not justiciable". 53

In Wachmann the court declined jurisdiction because the respondent was not a reviewable body, exercising functions "essentially intimate, spiritual, and religious - functions which the government could not and would not seek to discharge in his place were he to abdicate his regulatory responsibility" ${ }^{\prime 4}$, and the decision was not reviewable as to do so would "inevitably" draw the court into "adjudicating upon matters intimate to a religious community". 55

\footnotetext{
${ }^{50}$ Ibid [44].

51 Ibid [45].

52 Although today statutory provisions may 'provide a means of avoiding the judicial determination of a religious dispute' in both jurisdictions: [56]. The authors of Religion and Law in the United Kingdom distinguish between courts intervening where there is a financial interest (the 'Forbes v Eden principle': (1867) LR 1 Sc \& Div 568) and where the disposal and administration of property is at stake: 78 .

${ }^{53}$ Shergill (n 39) [58].

${ }^{54} R v$ Chief Rabbi of The United Hebrew Congregations of Great Britain and The Commonwealth ex parte Wachmann [1992] 1 WLR 1036, 1042.

55 Ibid 1043.
} 
The implication in the Supreme Court's consideration of Wachmann is that it was the absence of any cause of action on the "government function" test in public law that defeated the claim - the first reason given by Simon Brown $\mathbf{J}$ - and not the second, which alone would not have been enough to defeat a claim "presented as a challenge to the contractual jurisdiction of a voluntary association", where the court had jurisdiction to consider questions of ultra vires and allegations of breaches of natural justice. $^{56}$

The second basis rejected by the Court was that found in the grounds of Blake, a former Anglican clergyman who purported to conduct a samesex marriage on a TV programme.

Two pieces in the Daily Mail commented on the programme and described him variously as a "self-styled" and "imitation" bishop with a "costume mitre". ${ }^{57}$ In his claim for libel, Mr Blake pleaded that the articles alleged he was not validly consecrated nor entitled to call himself a bishop, although he "masqueraded" as one, and that he was "publicly and dishonestly" imitating a bishop, thereby setting out to deceive the public. $^{58}$

The publishers of the Mail disagreed with the precise meanings borne by the articles, but pleaded that "in all the circumstances $\mathrm{C}$ is an imitation bishop". It sought to defend the articles using the defences of justification and/or fair comment. ${ }^{59}$

After the exchange of pleadings and witness statements - the statements of the claimant and his witnesses were "redolent with doctrinal, procedural, jurisdictional and historical arguments in favour of validity of his consecration" $" 60$ - the judge decided that the pleaded issues were within the "territory which the courts, by self-denying ordinance, will not enter". 61

Gray $\mathrm{J}$ then moved on to consider whether the action should be stayed or proceed to trial, with perhaps some "adaptation of the issues as they stand at present". ${ }^{62}$ The claimant argued that underlying the doctrinal issue as to the validity of his consecration was a "secular issue" that could be

\footnotetext{
56 The reasoning in Wachmann has been described as 'suspect on several counts, not least since the test for judicial review is the present of "public" functions not "governmental": Doe, Religion and Law in the United Kingdom (n 2) 79.

${ }^{57}$ Blake (n 3) [1] - [10].

58 Ibid [11].

${ }^{59}$ Ibid [12]-[13].

${ }^{60}$ Ibid [17].

${ }^{61}$ Ibid [24].

${ }^{62}$ Ibid [25].
} 


\section{THE PROBLEM OF THE NON-JUSTICIABILITY OF RELIGIOUS DEFAMATIONS}

appropriately determined by the courts: whether the claimant had "in historical fact" been consecrated as a bishop. ${ }^{63}$ The claimant's expert opined that the claimant had been "clearly" consecrated a matter of historical fact, and that this was within "a valid historical succession", albeit one that may not be recognised by other churches. The complained of articles wholly neglected this context, generating the misleading impression he was an impostor. ${ }^{64}$ The defendant countered that nonjusticiable religious issues were so "fundamental" that the action could not be fairly tried. ${ }^{65}$

Gray J, who acknowledged that a stay should only be granted in most extreme circumstances as it would deny the claimant the opportunity of establishing good name in the courts, concluded that the issues in the action could not be adapted to "circumvent the insuperable obstacle placed in the way of a fair trial". ${ }^{66}$ He suggested that the claimant, who he found "understandably somewhat reluctant to abandon his claim to have been validly consecrated", should make a "modified version of the secular issue" the basis of the claim, before noting the sheer quantity and depth of issues in the case that came within the "forbidden" territory of nonjusticiability:

"Such questions include, by way of example only, substantive doctrinal questions including the canon law of catholic apostolic churches, questions of ecclesiastic procedure such as the authority and entitlement of Richard Palmer to consecrate the Claimant and the validity (in the absence at the time of any denomination or established church) of the consecration of the Claimant; questions whether the consecration of the Claimant was in conformity with the customs and practices of any established Christian denomination or criteria independently of POEM [the claimant's order] and finally questions as to the moral standing and fitness of both Richard Palmer and the Claimant for episcopal office." ${ }^{, 77}$

\section{THE IMPACT OF KHAIRA ON DEFAMATION CASES}

The Court does not explain precisely why the decision in Blake was incorrect; the thrust of its criticism is that, because a private right was

\footnotetext{
${ }^{63}$ Ibid [27].

${ }^{64}$ Ibid [28]-[30].

${ }^{65}$ Ibid [31].

${ }^{66}$ Ibid [35] and [38].

${ }^{67}$ Ibid [33].
} 
engaged, the claim should have proceeded to trial, even if that required the determination of religious doctrine, in order to give legal effect to the claimant's private rights. This is indicated by the fact that the Court was happy to remit a number of difficult questions about the dispute back for trial by the lower courts, including on the fundamental tenets of the First Holy Saint and the Nirmal sect, the nature of the institution at Nirmal Kutia in India, the steps or formalities were needed for a person to become the successor of the First Holy Saint, and whether the teachings and personal qualities of the Third Holy Saint comply with the fundamental religious aims and purposes of the trust. ${ }^{68}$

On this basis, the Court could have criticised other recent decisions applying the "fundamental and inseparable" test to religious doctrine. Similar matters arose in the parallel defamation proceedings in Baba Jeet $v$ Singh and Shergill $v$ Purewal. In Baba Jeet, the Third Holy Saint claimed that an article in the Sikh Times about the Nirmal Sikh faith damaged his reputation in the UK as it alleged he was the leader of a "cult" and an impostor who disturbed the peace in the Sikh community generally and in High Wycombe specifically, had dishonestly produced counterfeit trust deeds to remove the gurdwara trustees and management committee there, and promoted blasphemy and the sexual exploitation and abuse of women. ${ }^{69}$ In Purewal, the first claimant in Khaira brought a libel action against another Sikh newspaper, the Punjab Times, and a journalist for three articles that attacked the Third Holy Saint and his followers, including some of the trustee appointees. The articles claimed that the Third Holy Saint had abandoned Sikh principles, that he and his supporters were a "sham", and that the claimant had sought to instigate violence. $^{70}$

Both actions were stayed at preliminary issues hearings because issues of religion and doctrine permeated the pleadings and the courts did not consider it within their jurisdiction to determine the religious questions. For instance, the issue in Baba Jeet of whether the claimant was an "impostor" could not be isolated and resolved without reference to Sikh doctrines and traditions ${ }^{71}$, and the issues in Purewal, such as whether the Third Holy Saint was the legitimate successor to the sainthood, were

\footnotetext{
${ }^{68}$ Khaira [59].

${ }^{69}$ Baba Jeet [8].

${ }^{70}$ Purewal [1]-[8].

${ }^{71}$ Baba Jeet [41] (Eady J) following the reasoning in Blake (n 3). The Third Holy Saint successfully obtained permission to appeal but a substantive appeal not heard as he failed to pay security for costs: His Holiness Sant Baba Jeet Singh Ji Maharaj v Eastern Media Group and Anr [2011] EWCA Civ 139.
} 


\section{THE PROBLEM OF THE NON-JUSTICIABILITY OF RELIGIOUS DEFAMATIONS}

"fundamental" to the case, making it "impossible to adapt the issues in such a way as to circumvent the insuperable obstacle placed in the way of a fair trial of the action by the fact that the court is bound to abstain from determining questions which lie at the heart of the case". ${ }^{72}$ Applying Khaira, it is likely that both cases should have gone to trial given the engagement of the claimants' private law rights. Nothing distinguishes either from Blake.

It seems that the Supreme Court has subverted the basis for these decisions. Being founded on a religious dispute does not disqualify a legal dispute as non-justiciable per se, whether or not the claim can be reframed in secular terms (it does if it is purely a religious dispute, however). The Court has preferred the claimant's right to vindication of reputation over the defendant's rights in the action, against authority in a line of cases such as Prebble, Hamilton and Greer $v$ Hencke", and Blake: "the newspaper would still wish to advance the case that the consecration service had no religious or ecclesiastic validity, so that it was in effect a charade, and that to prevent the newspaper from advancing this case would be manifestly unfair and a serious invasion of its Article 10 right". 74

Furthermore, the Court, through its support for Lord Davey's prohibition in Overtoun, appears not to permit courts to decide the "truth" of religious doctrines. ${ }^{75}$ It seems doubly unfair on the defendant if defamation claims underlain by religious disputes are justiciable but the truth of the religious dispute cannot be contemplated in its own terms nor repleaded in wholly non-doctrinal ones.

A solution (or at least a "preferable means of accommodating religion in the law of libel" $"$ ) may lie in the reformulation of the defence of honest

\footnotetext{
${ }^{72}$ Purewal [35] (Gray J) .

7321 July 1995, May J. To look for another basis for the claim would be 'both unfair to the defendants and quite impractical'.

${ }^{74}$ Blake [36]. See also [31] where the defendant averred that Otto-PremingerInstitut v Austria [1994] EHRR 34 and s 12(4) of the 1998 Human Rights Act supported the proposition that 'if the right of the newspaper to deploy material in support of the defences of justification and fair comment were to be circumscribed by the court, its right to freedom of expression under art 10 [ECHR] might be infringed'. S 12(4) obliges the court pay 'particular regard' to the 'importance of the Convention right to freedom of expression' and, inter alia, to the benefit of any defendant respondent, the extent of publication and whether publication was in the public interest.

${ }^{75}$ See [45] and [53].
${ }^{76}$ Mullis and Scott (n 20) 144.
} 
opinion. The Supreme Court alluded to the previous formulation of the defence in Spiller $v$ Joseph in Khaira. ${ }^{77}$ Currently, under s 3, a "fact" for the purposes of the defence must be something the defendant can prove is true. This does not get the religious doctrine dispute any further than the defence of justification. But if "fact" for the purposes of honest opinion meant the allusion to or representation of the religious doctrine dispute itself, this would form the basis of the defence provided the other conditions in the defence are satisfied.

This would not give the defendant the same protection as a strike-out of the claim on the basis of non-justiciability, described as "an absolute privilege which has never been recognised and could easily be abused" but it would provide critics and commentators with a safer defence provided they refer to the doctrinal dispute in their publication. It would, in effect, extended the concept of privilege, already acknowledged in the honest opinion defence, beyond its established domains of absolute and qualified privilege, and rebalance the scales of justice between the parties in religious defamation disputes.

\section{CONCLUSION}

Khaira does more than "shift...the boundary slightly and enlarge the circumstances in which the court will feel able to intervene",79 or merely "push the door of non-justiciability open by a crack" ${ }^{80}$ It potentially heralds a return to what has been described as the "nineteenth century" concept of non-justiciability, where judges sought "neutrality" and detachedness by "pointing out that it was no role of a court of law to act as a religious insider delivering "correct" answers to the underlying substantive theological or ecclesiological dispute between the parties" but would "regularly proceed to point out that questions of doctrine and

\footnotetext{
77 [57].

${ }^{78}$ Otuo (n 23) [25].

${ }^{79}$ Frank Cranmer, 'Is Religious Doctrine Justiciable? Up to a Point, Yes: Shergill v Khaira' Law \& Religion UK, 11 June 2014,

$<$ www.lawandreligionuk.com/2014/06/11/is-religious-doctrine-justiciable-up-toa-point-yes-khaira-v-shergill/> accessed 15 July 2015.

${ }^{80}$ Neil Addison, 'Shergill v Khaira - When can Religious Doctrine be Justiciable?' (Religion Law, 12 June 2014)

$<$ http://religionlaw.blogspot.co.uk/2014/06/shergil-v-khaira-when-canreligious.html> accessed 1 July 2015.
} 


\section{THE PROBLEM OF THE NON-JUSTICIABILITY OF RELIGIOUS DEFAMATIONS}

discipline might well be relevant as questions of fact to determine the outcome of the case" through the use of evidence. ${ }^{81}$

Particularly given the willingness of courts to widen the legal definition of a religion, for instance to the Church of Scientology, ${ }^{82}$ it is hard to disagree with Singh that there is likely to be a rise in defamation cases involving religion, more of which will be deemed justiciable. ${ }^{83}$ There has even been an attempt at a private prosecution on the basis of the "untruth" of the Mormon faith. ${ }^{84}$ More cases will involve religions other

${ }^{81}$ Julian Rivers, The Law of Organized Religions: Between Establishment and Secularism (OUP 2010) 73. This is in contrast to the 'modern doctrine', which holds that courts should 'not even resolve disputed questions of religious doctrine and government as matters of fact'. It is 'thus a form of blindness to social reality and the expectations of the parties. It leads to a curious instability in the law' between denial of a remedy to the claimant on the one hand, or the search for a wholly non-religious basis for legal decision-making on the other. See also Rivers' preference for the secular approach to Blake (n 3) 145: 'One can easily distinguish between claims which are simply true or false (eg that a person does or does not hold a certain position in a certain religious organization) and claims which depend on a theological judgment....'

${ }^{82} R v$ Registrar General of Births, Death and Marriages ex parte Hodkin [2013] UKSC 77, reversing the principle of the Court of Appeal in $R v$ Registrar General, ex parte Segerdal [1970] 2 QB 697.

83 'Reports on those alleged to be involved with Islamic extremism and charismatic [new religious movement] leaders, along with the increased use of social media, provide ample opportunity for the issuing of further defamation writs. Religious practitioners with deep pockets want to manage reputations just like everyone else. They should also expect to be held accountable for their transgressions.' <https://inforrm.wordpress.com/2015/03/11/a-leap-of-faith-therise-of-religious-libel-cases-hardeep-singh/> accessed 15 July 2015.

${ }^{84}$ Thomas Phillips v Thomas Monson [2014] Westminster Magistrates Ct (District Judge Riddle): 'It is obvious that this proposed prosecution attacks the doctrine and beliefs of the Mormon Church, and is aimed at those beliefs rather than any wrong-doing of Mr Monson personally. The purpose is to use criminal proceedings to expose the false (it is said) facts on which the church is based. It is inevitable that the prosecution would never reach a jury, even if Mr Monson chooses to attend. To convict, a jury would need to be sure that the religious teachings of the Mormon Church are untrue or misleading. That proposition is at the heart of the case. No judge in a secular court in England and Wales would allow that issue to be put to a jury. It is non-justiciable.' <www.judiciary.gov.uk/wp-content/uploads/JCO/Documents/Judgments/thomasphillips-v-thomas-monson.pdf> accessed 15 July 2015. 
than Christianity, as new religious movements (NRMs) use threats of libel to silence critics. ${ }^{85}$

Nonetheless, these cases will demand resolution by the courts: whereas the property law cases cited by the Supreme Court were potentially open to alternative dispute resolution (such as mediation) where all parties could be partially satisfied through the division of the trust property amongst them, in defamation cases such division is not possible: either the claimant vindicates their reputation, or the libel stands. There is no halfway house. Damage to reputation is not easily repaired nor, in the eyes of many claimants, adequately restored by damages. Many will welcome the decision in Khaira.

At the same time, most of the occasions on which the courts have decided religious truths as the basis for enforcing secular rights and obligations have concerned underlying Christian theology. Given the composition of the judiciary it is reasonable to infer that most judges will be much more familiar with Christian doctrine and practice than with Hinduism or Islam. The invitation in Khaira could thus herald an avalanche of defamation claims in a range of familiar religions and NRMs. This would possibly be counter-cultural given the cultural and political shift towards defences of free speech, perhaps seen more glaringly after the Charlie Hebdo killings.

The Magna Carta ends with a peroration at article 63:

"IT IS ACCORDINGLY OUR WISH AND COMMAND that the English Church shall be free, and that men in our kingdom shall have and keep all these liberties, rights, and concessions, well and peaceably in their fullness and entirety for them and their heirs, of us and our heirs, in all things and all places for ever."

Such a pronouncement was satisfactory for the relative cultural homogeneity of the thirteenth century. 800 years later, it is the balance between the liberty of the churches in their doctrines, and the right of reputation of "men in our kingdom", that is at stake today.

${ }^{85}$ Religious Libel, 153-54. 